\title{
MTQ; \\ ANTARA SENI MEMBACA ALQURAN DAN POLITIK AKOMODASIONIS PEMERINTAH TERHADAP UMAT ISLAM
}

\author{
Sri Handayana \\ LAIN Metro Lampung, handayana.sri@gmail.com \\ Muhamad Rezi \\ IAIN Bukittinggi, rezineddin@gmail.com
}

Diterima: 24 Agustus 2018

Direvisi : 11 November 2018

Diterbitkan: 30 Desember 2018

\begin{abstract}
MTQ is a manifestation of Islamic culture and is constantly evolving. MTQ is also one of the government policies related to Muslims and even seems to accommodate the interests of Muslims. The author believes that $M T Q$ can be investigated from various aspects. If viewed from a religious perspective, $M T Q$ is one way to improve spiritual life. If viewed from an economic standpoint, $M T Q$ can support economic development through exhibitions or bazaars held in the main arena. Whereas if it is highlighted with the political glasses of MTQ perhaps on the one hand the government is accommodating towards Muslims. This paper attempts to describe MTQ and its ins and outs, then also attempts to analyze MTQ as a form of aesthetic reception of the Qur'an and the political dimension of MTQ. The effort to express the Koran aesthetically has actually emerged since the time of the Prophet Mubammad. One of the most popular stories is about the Islamic story of Umar ibn Khattab after hearing the reading of several verses of the Qur'an by his younger sister named Fatimah with her husband named Sa'id bin Zayd. Therefore MTQ is an opportunity to develop the art of reading the Qur'an, and an event to foster awareness to read and study the Qur'an.
\end{abstract}

Keywords: MTQ, Membaca Alquran, Politik Akomodasionis

\begin{abstract}
Abstrak
MTQ merupakan manifestasi budaya Islam dan senantiasa mengalami perkembangan. MTQ juga satu di antara kebijakan pemerintah yang terkait dengan umat Islam babkan terkesan mengakomodasi kepentingan umat Islam. Penulis berpendapat bahwa MTQ bisa diteliti dari berbagai aspek. Jika dilihat dari sudut agama, MTQ adalah salab satu cara untuk. meningkatkan kehidupan spiritual. Apabila ditinjau dari sudut ekonomi MTQ dapat menunjang perkembangan ekonomi melalui pameran atau bazaar yang diadakan di arena utama. Sedangkan jika disorot dengan kacamata politik. MTQ mungkin di satu sisi pemerintah bersikap akomodatif terhadap umat Islam. Tulisan ini berusaha untuk mendeskripsikan tentang MTQ dan seluk beluknya, kemudian juga berupaya untuk menganalisis MTQ sebagai bentuk resepsi estetik terhadap Alquran dan dimensi politik dari MTQ. Upaya mengekspresikan al-Quran secara estetike sesunggubnya sudah muncul sejak zaman Nabi Mubammad Saw. Salah satu kisah yang cukup populer adalah tentang kisah keislaman Umar ibn Khattab setelah mendengar pembacaan beberapa ayat Alquran oleh adik perempuannya yang bernama Fatimah bersama suaminya yang bernama Sa'id bin Zayd. Oleh karena itu MTQ merupakan kesempatan untuk mengembangkan seni membaca Alquran, dan ajang untuk menumbubkan kesadaran untuk membaca dan mempelajari Alquran.
\end{abstract}

Kata Kunci: MTQ, Membaca Alquran, Politik Akomodasionis 


\section{PENDAHULUAN}

Musabaqah Tilawatil Qur'an atau disingkat MTQ merupakan manifestasi budaya Islam dan senantiasa mengalami perkembangan. MTQ juga satu di antara kebijakan pemerintah yang terkait dengan umat Islam bahkan terkesan mengakomodasi kepentingan umat Islam. Penulis berpendapat bahwa MTQ bisa diteliti dari berbagai aspek. Jika dilihat dari sudut agama, MTQ adalah salah satu cara untuk meningkatkan kehidupan spiritual. Apabila ditinjau dari sudut ekonomi MTQ dapat menunjang perkembangan ekonomi melalui pameran atau bazaar yang diadakan di arena utama. Sedangkan jika disorot dengan kacamata politik, MTQ mungkin di satu sisi pemerintah bersikap akomodatif terhadap umat Islam tetapi di sisi lain secara tidak langsung juga upaya pemerintah menarik hati umat umat Islam di Indonesia. Tulisan ini berusaha untuk mendeskripsikan tentang MTQ dan seluk beluknya, kemudian juga berupaya untuk menganalisis MTQ sebagai bentuk resepsi estetik terhadap Alquran dan dimensi politik dari MTQ.

\section{SEJARAH PERKEMBANGAN MTQ DI INDONESIA}

Pembacaan Alquran di Indonesia berkembang seiring dengan perkembangan dakwah Islam. Begitu juga dengan tradisi menghafal dan serta mempelajari tafsirnya. Pada awal kedatangan Islam di Indonesia, perkembangan pembelajaran Alquran masih dalam bentuk sederhana dan menyatu dengan kegiatan dakwah. Tradisi pembacaan Alquran mulai mengalami perkembangan yang cukup signifikan pada abad ke 18 ketika terjadi kontak langsung antara Indonesia dan Jazirah arab serta para ulama yang belajar di Timur Tengah pulang ke Indonesia. Kemudian pada tahun 1605 M, raja Gowa ke-16 Sultan
Alauddin memeluk Islam. Maka setiap bulan Ramadhan diadakan tadarus di istana raja. ${ }^{1}$

Lalu pada masa itu bermunculanlah ulama ahli Alquran, di antaranya, $\mathrm{KH}$. Munawir di Yogyakarta, KH. Abbas di Buntet, Cirebon, KH. 'Isyam dan KH. Hisyam di Salatiga, Syekh Abu Samah di Padang, KH. Mukhtar Lutfy di Makasar, dan lain-lain. Sistem pengajaran pada waktu itu dimulai dengan menghafal bacaan shalat, huruf hijaiyah melalui kaidah Baghdadiyah, dan juz 'Amma. Selanjutnya mengaji Alquran secara keseluruhan. Kegiatan ini biasanya dilakukan di lingkungan keluarga atau guru dan buya di masjid atau mushalla, karena diikuti oleh anakanak usia 5-12 tahun. Di sini mereka menamatkan bacaan Alquran dan mempelajari ibadah-ibadah praktis. ${ }^{2}$

Kontak langsung dengan jazirah Arab juga memberikan pengaruh pada tilawah Alquran. Alquran mulai dibaca dengan tajwidnya dan diiringi dengan lagu-lagu (naghm) yang indah. Pada awalnya tilawah Alquran di Indonesia dipengaruhi lagu Makkamî yang dibawa oleh ulama nusantara yang baru pulang menuntut ilmu dari Makkah. Lalu terjadi revolusi lagu tilawah Alquran di Indonesia dari lagu makkawî beralih menjadi lagu mishrî. Perubahan ini terjadi karena kunjungan para qari' Mesir ke Indonesia setiap bulan Ramadhan. ${ }^{3}$ Lagu mishrî terdiri dari tujuh lagu: bayyâti, hijâz, shabâ, râst, jihârkah, sîkâ, dan nahâwan. Lagu ini selanjutnya menjadi lagu resmi dalam MTQ Nasional.

Dalam waktu relatif singkat berdiri jam'iyyatul qurra wal buffaz di berbagai daerah di Indonesia. Berbarengan dengan perkembangan membaca, menghafal serta mempelajari

${ }^{1}$ LPTQ, 25 Tabun Musabaqah Tilawatil Qur'an dan 17 tabun Lembaga Pengembangan Tilawatil Qur'an, (Jakarta: Lembaga Pengembangan Tilawatil Qur'an Tingkat Nasional, 1415H/1994 M), hlm. 14

2 LPTQ, 25 Tabun Musabaqah Tilawatil Qur'an..., hlm. 15

3 LPTQ Provinsi DKI Jakarta, Dari Jakarta Untuk Indonesia Sejarah LPTQ Provinsi DKI Jakarta, (Jakarta: LPTQ Provinsi DKI Jakarta, 2008), hlm. 21 
Alquran ini kemudian muncul perlombaan membaca Alquran. Perlombaan yang pertama kali tercatat di Kampung Bunga, Asahan, Sumatera Utara pada tahun 1946 diprakarsai oleh Ustadz Muhammad Ali Umar, pimpinan Persatuan Agama Islam setempat. ${ }^{4}$ Pada saat itu, perlombaan membaca Alquran belum memakai nama 'musabaqah'. Meskipun mendapat tantangan, tetapi lomba tersebut berjalan lancar dan diikuti sekitar 300 peserta. Selain itu pada tahun 1949 juga diadakan lomba baca Alquran yang diikuti oleh Qariqari dari Sulawesi Selatan dan Kalimantan. Sedangkan di Jakarta sendiri lomba membaca Alquran diadakan pertama kali pada tahun 22 Juni 1952 dalam rangka memperingati hari ulang tahun kota Jakarta yang diikuti para qari dewasa dan pelajar se-DKI Jakarta. ${ }^{5}$

Istilah musabaqah pertama kali digunakan pada tahun 1953-1954. Pada tahun 1952 diadakan sayembara membaca Alquran di Pontianak, yang diikuti oleh para qari dari Pontianak, Sambas, dan Ketapang. ${ }^{6}$ Ketika dilaksanakan untuk yang kedua kalinya pada tahun 1953, sayembara diganti dengan musabaqah atas usulan berbagai pihak. Istilah musabaqah mengacu pada ayat "fastabiqul khairat". Di Masjid Syuhada Yogyakarta, penggunaan kata musabaqah merupakan saran dari Prof. T. M. Hasby Ash-Shiddieqy ketika memilih qari terbaik se-Yogykarta dan Jawa Tengah tahun $1954{ }^{7}$

\section{PERKEMBANGAN MTQ NASIONAL}

Perkembangan pembacaan Alquran yang demikian pesat mendapat apresiasi dari pemerintah. Pada tahun 1962 Menteri Agama KH. Saifuddin Zuhri menetapkan pentingnya diadakan Latihan Membaca Alquran di jawatan Pendidikan agama untuk meningkatkan mutu dan kemampuan murid-murid madrasah dalam

\footnotetext{
4 LPTQ, 25 Tabun Musabaqah Tilawatil Qur'an..., hlm. 18

${ }^{5}$ Ibid., hlm. 18

${ }^{6}$ Ibid.

${ }^{7}$ Ibid.,
}

membaca Alquran. Sebagai aplikasi, maka diadakanlah MTQ untuk kalangan muridmurid madrasah dilingkungan Departemen Agama, mulai dari tingkat sekolah, kabupatenkota, propinsi hingga pusat. ${ }^{8}$ Meskipun masih terbatas untuk pelajar madrasah, tetapi dapat dikatakan sebagai embrio menuju MTQ nasional yang dimulai pada tahun 1968. Berdasarkan uraian tadi Nampak bahwa faktor intern telah mendorong lahirnya MTQ nasional. Selain itu ada juga faktor ektern yakni kebutuhan pengutusan qari-qariah dalam MTQ International yang mulai diadakan di Kuala Lumpur pada tahun 1958.

MTQ nasional pertama kali diadakan di Makasar pada bulan Ramadhan pada tahun 1968. Pada saat itu yang diperlombakan baru cabang tilawah golongan dewasa putra dan putri. Kemudian format MTQ menjadi semakin berkembang. MTQ nasional kedua dilaksanakan di Jawa Barat tahun 1969. Pada saat itu cabang yang diperlombakan menjadi 3 golongan; golongan dewasa, pelajar tsanawiyah, dan pelajar ibtida'iyah. Pada MTQ nasional kelima di Jakarta, mulai ada tradisi baru yakni pembangunan yang bersifat monumental, diskusi, pameran, dan piala bergilir dari Presiden Soeharto bagi juara umum. Kemudian pada MTQ nasional ketujuh di Jawa Timur bertambah satu cabang lagi yakni golongan tuna netra. Cabang hifzil qur'an (MHQ) dimulai pada tahun 1981 saat MTQ nasional ke 12 di Aceh. Sedangkan cabang fahmil qur'an (MFQ) dimulai pada tahun 1983 pada MTQ nasional ke 13 di Padang, Sumatera Barat. Adapun cabang khattil qur'an (MKQ), syarhil qur'an (MSQ), tafsirul qur'an (MTQ) mulai diperlombakan pada MTQ nasional ke15 tahun 1988 di Lampung. Selain itu juga ada penambahan pada cabang hifzil qur'an yakni golongan 20 juz, 10 juz, dan 1 juz tilawah. Pada MTQ nasional ke 32 di Bengkulu tahun 2010 dikembangkan satu cabang lagi yakni menulis

${ }^{8}$ Ibid., hlm. 21 
kandungan Alquran atau disingkat M2KQ. Jadi total semua golongan yang diperlombakan dalam MTQ nasional adalah 20 golongan.

\section{MTQ DALAM PERSPEKTIF}

Alquran sebagai firman Allah merupakan teks sakral yang memperoleh penjagaan ketat dari kerusakan (penambahan atau pengurangan) dan perubahan. Allah sendiri telah menjanjikan akan menjaga kitab tersebut seperti dalam firman-Nya "Sungguh Kamilah yang menurunkan (Alquran) dan Kamilah yang menjaganya" (QS. 15: 9). Di samping itu, kaum muslimin juga melakukan penjagaan Alquran mulai dari pembacaan hafalan berikut dengan semaannya hingga menjadi sebuah Musabaqah yang dinaungi oleh LPTQ. Maka secara tekstual dan substansial, Alquran memang tidak mungkin mengalami perubahan dan kerusakan, akan tetapi sebagai teks tulis Alquran masih membuka kemungkinan untuk diresepsi. Salah satu bentuk resepsi Alquran adalah resepsi estetik.

Resepsi diartikan sebagai sebuah pendekatan yang menitikberatkan unsur konsumen (pembaca) dalam melakukan konkretisasi terhadap suatu karya sastra. Salah satu tokoh teori ini adalah Hans Robert Jauss. Ia berpendapat bahwa sebuah teks harus dipelajari terutama dalam kaitannya dengan reaksi pembaca (estetika resepsi). Jauss mengatakan kehidupan historis sebuah karya tidak terpikirkan tanpa partisipasi pembacanya. ${ }^{9}$ Hal itu menunjukkan bahwa pembaca mempunyai peran aktif dalam penafsiran, bahkan merupakan kekuatan pembentuk sejarah. Dengan kata lain, teori ini berusaha untuk mempelajari relasi-relasi antara masa lampau dan zaman si pembaca, sehingga teori ini berangkat dari peran pembaca dalam

9 Rachmat Djoko Pradopo, "Estetika Resepsi dan Teori Penerapannya", dalam Sulastri Sutrisno (ed) dkk, Bahasa, Sastra, dan Budaya, Yogyakarta: UGM Press, 1991), hlm. 185 proses pembacaan. Pada saat membaca, ia mempunyai sebuah bekal yang disebut horizon harapan. Inilah yang menyebabkan penerimaan (resepsi) yang berbeda-beda. Di sini juga terlihat interaksi teks dan pembaca.

Resepsi estetik terhadap Alquran sendiri berangkat dari keyakinan bahwa Alquran merupakan kitab suci yang memiliki bahasa yang indah. Keindahan ini dianggap oleh Quraish Shihab sebagai salah satu mu'jizat Alquran. ${ }^{10}$ Keindahan bahasa Alquran juga direspon dalam berbagai bentuk seperti melagukan bacaannya hingga melombakan dalam bentuk MTQ.

Mahmoud Ayoub mengatakan:

Traditionally, Muslims have approached the Qur'an from two distinct, but interrelated, point of view, as the Qur'an interpreted and the Qur'an recited. To the former, Muslims have dedicated their best minds, and to the later their best voices and musical talents ${ }^{11}$

Biasanya, umat Islam mendekati Alquran dengan dua pendekatan yang berbeda namun saling terkait, Alquran sebagai teks yang ditafsirkan dan Alquran sebagai teks yang dibaca. Untuke yang pertama, umat Islam telah mencurabkan kemampuan terbaik mereka dan yang kedua, mereka membacanya dengan suara yang indah dan talenta musik mereka.

Dalam bentuk asalnya membaca Alquran merupakan suatu pelaksanaan ajaran, suatu ibadah, dan bentuk persembahan dan pengabdian seorang hamba kepada Allah. Oleh karena itu tidak salah pernyataan Mahmoud Ayoub tadi bahwa segala pendekatan pun dilakukan, dengan membacanya, menghafalnya (atau dikenal dengan tradisi semaan), dan mempelajarinya. Qurra' dan buffaz, selalu tampil dari berbagai generasi. Para ulama klasik hingga

\footnotetext{
10 Quraish Shihab, Mu'jizat alQur'an, (Bandung: Mizan, 1997), hlm. 118-131

11 Mahmoud Ayoub, "the Qur'an Recited", dalam

http://w3fp.arizona.edu/mesassoc/Buletin/Ayoub
} 
kontemporer berusaha untuk menggali maknanya dengan menyusun kitab-kitab tafsir dan ilmu-ilmu Alquran dengan menggunakan berbagai perangkat keilmuan. Semua ini merupakan bentuk pengabdian dalam rangka mewujudkan fungsi utamanya sebagai pembimbing manusia ke jalan yag lurus:

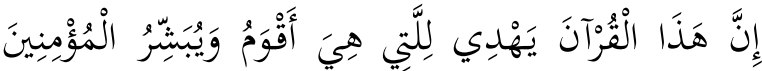

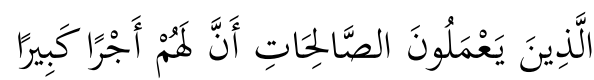

Sesunggubnya Al Quran ini memberikan petunjuk kepada (jalan) yang lebih Lurus dan memberi khabar gembira kepada orang-orang Mu'min yang mengerjakan amal saleh bahwa bagi mereka ada pabala yang besar,(QS. Al-Isra’: 9)

Dalam prakteknya, selain dihafal dan ditafsirkan, membaca Alquran mempunyai dua bentuk resitasi, murattal dan mujawwad. Yang umum adalah murattal karena bentuknya yang sederhana sehingga bisa dibawakan oleh semua orang tanpa banyak tuntutan skill yang rumit. Ibadah sholat, tadarrus, dan kegiatan belajar Alquran biasanya menggunakan gaya murattal. Sebaliknya resitasi mujawwad adalah gaya untuk para professional yang memiliki kemampuan musical dan sentuhan seni lebih. Di Indonesia gaya ini disebut nagham sedangkan di Malaysia disebut tarannum. ${ }^{12}$ Lagu

12 Uraian selengkapnya lihat Christina Nelson, The Art of Reciting the Qur'an, (USA: University of Texas Press, 1985), hlm. 68-100. Menurut Ibn Manzur, orang yang pertama membaca al-Qur'an dengan lagu adalah Ubaidillah bin Abi Bakrah, selanjutnya Said al-Allaf alIbadi. Menurutnya, lagu al-Qur'an ini berasal dari nyanyian budak kafir yang tertawan ketika perang antara umat Islam dan kaum kafir. Ada juga yang mengatakan bahwa lagu al-Qur'an ini berasal dari nyanyian nenek moyang bangsa Arab. Selengkapnya lihat Ibn Manzur, Lisân al-'Arab, (Ttp:Dâr Ihya' al-Turast al-'Araby, 630 $\mathrm{H})$, hlm. 23-24. Ibn Qutaibah menambahkan bahwa lagu al-Qur'an berbeda dengan musik biasa. Bacaannya sedih (bu₹n) dengan suara yang lunak dan belum ada unsur lagu menyanyinya. (al-ghinâ). Lagu al-Qur'an ini kebanyakan dibawakan oleh laki-laki karena dalam budaya Arab perempuan tidak boleh tampil di depan umum kecuali di depan sekumpulan perempuan. Masalah lagu al-Qur'an ini pun semakin menarik karena ada tarik ulur hukum boleh atau tidaknya. Keduanya juga memberikan dalil-dalil yang seimbang. Yang melarang untuk melagukan al-Qur'an menganggap untuk gaya mujawwad ini pun juga mengalami revolusi. Di Indonesia terlihat bagaimana kecenderungan para qurra Indonesia mengalami perubahan dari gaya makki ke gaya misri.

Membaca Alquran (tilawah Alquran) juga merupakan pintu masuk untuk menyelami kedalaman dan keluasan maknanya. Bila semua orang tak sanggup menyelami kedalaman dan keluasan maknanya, setidaknya mereka dapat merasakan keagungannya dengan membacanya, terlebih dengan tartil. Tartil merupakan suatu aturan membaca dengan nada dan ritme yang tepat. Apalagi bila firman Allah dilantunkan dengan lagu atau nagham.

Maka tak heran jika tilawah Alquran mengakar dan tumbuh subur di Indonesia, meskipun bangsa non-Arab. Tilawah Alquran kemudian menyebar, para qari bermunculan, dan mulai berpindah ke ranah lain. Kelompokkelompok pengajian tilawah Alquran menjamur di berbagai daerah Indonesia. Maka apresiasi itu secara kuantitatif dan kualitatif bermuara pada lomba membaca Alquran yang kemudian dikenal dengan MTQ yang dari tahun ke tahun menjadi pesta budaya keagamaan yang sarat makna.

Menurut Mukti Ali, Alquran mempunyai dimensi yang sangat luas dan dapat menimbulkan tiga hal sekaligus, seni, ilmu, dan agama. ${ }^{13}$ Dengan seni hidup menjadi lebih indah, dengan agama dan ilmu hidup menjadi lebih bermakna. Tanpa seni hidup menjadi kasar, tanpa ilmu dan agama hidup

ketidaklayakan memakai teori musik untuk al-Qur'an atau pengalihan dari meresapi makna al-Qur'an menjadi sekedar sebuah penampilan musik semata. Sebenarnya lagu al-Qur'an juga unik karena tidak ada patokan notasi. Lagu ini bersifat non-pragmatik dan lebih ke arah improvisasi vocal solo. Oleh karena itu yang membolehkan dilatarbelakangi pertimbangan estetik ini.

${ }^{13}$ Maria Ulfa, "Musabaqah Tilawah al-Qur'an", dalam LPTQ Provinsi DKI Jakarta, Dari Jakarta Untuk Indonesia..., hlm. 81 
menjadi sulit dan tidak bermakna. Di anatra Sahabat nabi sendiri ada yang membaca Alquran dengan bacaan yang menarik dan suara yang merdu, seperti Abu Musa al-Asy'ari. Rasullah sangat senang mendengarkannya dan berkata kepadanya bahwa ia telah dikaruniai suara seperti seruling Nabi Daud. ${ }^{14}$

Di dalam Alquran juga terdapat ayat yang menganjurkan bacaan Alquran dengan tartil:

$$
\text { وَرَتبّلِ الْقُرْآنَ تَرْتِيًَا }
$$

Dan bacalah Al Quran itu dengan perlahanlahan.(QS. al-Muzammil: 4).

Di dalam hadis juga banyak didapati anjuran untuk melagukan bacaan Alquran, di antaranya; Allah tidak pernah mendengarkan sesuatu sebagaimana ia mendengarkan Nabi sedang melagukan Alquran dengan suara merdu dan keras. (HR. Abu Daud) Dalam hadis lain juga disebutkan bahwa: Tidak termasuk golongan kami orang yang tidak mau melagukan Alquran. (HR. Abu Daud dari Sa'id bin Abi Sa'id dengan sanad yang baik)

Dengan demikian dapat disimpulkan bahwa Alquran dan hadis sangat menganjurkan untuk membaca Alquran. Namun masalah timbul ketika dihadapkan pada realitas bahwa MTQ bukan merupakan suatu ibadah yang secara eksplisit tertulis dalam Alquran dan hadis. Namun secara implisit MTQ dilegitimasi oleh QS. Al Baqarah: 148 melalui kata "fastabiqul khairat"; dan bagi tiap-tiap umat ada kiblatnya (sendiri) yang ia menghadap kepadanya. Maka berlomba-lombalah (dalam membuat) kebaikan. di mana saja kamu berada pasti Allah akan mengumpulkan kamu sekalian (pada bari kiamat). Sesunggubnya Allah Maha Kuasa atas segala sesuatu. Dan hadis: "biasilah rumahmu dengan bacaan Alquran" dan hadis "sebaik-baik kamu adalah orang yang

${ }^{14}$ Abu Zakariya bin Syarf al-Nawâwî, al-Tibyân fi Ádâb Hamalah al-Qur'an, (Beirut: Dâr Ibn Hazm, tth) hlm. 84 mempelajari Alquran dan mengajarkannya”. (HR. Bukhari)

Berdasarkan ayat dan hadis-hadis tadi maka seorang ahli fiqih Mesir yang bernama Syekh Umar Hubais memandang MTQ sebagai amal saleh dan tidak bertentangan dengan syari'at. Hamka menyatakan bahwa MTQ bukanlah sebuah bid'ah. ${ }^{15}$ Selain itu, secara fungsional MTQ memiliki fungsi integratif, yakni sebagai sarana ukhwah untuk menyatukan umat Islam. MTQ dapat mempererat ukhwah islâmiyah di antara peserta dan official khususnya, antara perserta dari satu khafilah dengan khafilah lain, atau antara peserta dengan masyarakat tuan rumah. MTQ juga berperan dalam menyeragamkan bacaan Alquran di tengah masyarakat.

MTQ merupakan sarana pendidikan untuk memasyarakatkan nilai-nilai Alquran di tengah masyarakat. Penyelenggaraan MTQ diharapkan bisa memacu masyarakat untuk kembali gemar membaca dan mempelajari Alquran. Peran edukatif ini dapat dirinci menjadi beberapa poin: pertama, menumbuhkan kesadaran untuk mempelajari Alquran. Kesadaran ini ditandai dengan fenomena menjamurkan lembaga kequr'anan mulai dari tingkat anak-anak seperti TPA, dan MDA. Fenomena ini juga dapat terlihat dari materi-materi yang diperlombakan pada Fahmil Qur'an (MFQ). Kedua, menumbuhkan kesadaran dalam pengembangan Alquran dalam bentuk perguruan tinggi yang concerm terhadap Alquran, misalnya STIQ, IIQ, dan STAIPIQ.

Fungsi edukatif juga dapat dilihat pada bentuk hadiah yang diberikan kepada para juara. Hadiah merupakan motivasi untuk memacu semangat untuk meningkatkan kemampuan. Biasanya hadiah berbentuk haji, uang tunai, dan beasiswa. Kemudian di tambah dengan bonus dari pemerintah daerah.

15 Irwan Abdullah, dkk (Ed), Dialektika Teks Suci Agama: Strukturisasi Makna Agama dalam Kebidupan Masyarakat, (Yogyakarta: Pustaka Pelajar, 2008), hlm. 2 
Kemudian hadiah berupa haji dialihkan ke dalam bentuk beasiswa dengan tujuan untuk meningkatkan mutu pendidikan bangsa. MTQ juga mendorong kreativitas masyarakat. Hal ini tampak dari sayembara untuk membuat lambang dan menciptakan Mars MTQ. Yang menjadi pemenang adalah Agus Sunaryo (Mars Gema MTQ) dan Ahmad Nasibu (Piala MTQ), dan Ahmad Syaukani (lambang MTQ). ${ }^{16}$

Ada juga beberapa tokoh yang menentang pelaksanaan MTQ. Hasbi ashShiddieqy salah satunya. Beliau berpendapat melombakan Alquran dengan lagu dan maksud keduniaan adalah bid'ah idhafah. Syekh Abdul Wahab juga mengharamkan dengan menyatakan bahwa tidak ada dalil yang membolehkan Alquran sebagai bacaan perlombaan. MTQ juga dapat menimbulkan benih ujub dalam diri peserta dan menanamkan persaingan antar daerah. Hasbi juga beranggapan bahwa masih banyak cara untuk memasyarakatkan pembacaan Alquran tanpa menghambur-hamburkan uang negara. ${ }^{17}$

Sementara dari dimensi politik, MTQ dapat ditinjau dari sisi relasi negara dan agama. MTQ lahir pada masa orde baru. Adapun hubungan negara dan Islam pada mas Orba mengalami pasang surut, mulai dari kenangan manis hingga tragis. Pada awal konsolidasi pemerintahan Orba, timbul optimism di kalangan umat Islam khususnya dan masyarakat umumnya karena romantisme perjuangan terhadap orde lama yang sarat dengan retorika demokrasi. Umat Islam memiliki harapan untuk terlibat lagi dalam dunia perpolitikan. Tetapi keinginan tersebut tidak terwujud karena bertentangan dengan srategi pembangunan Orba yang memarginalisasi perkembangan partai politik dan menganggap tabu pembicaraan seputar ideologi terutama agama. Menurut Abdul Aziz

\footnotetext{
17 Irwan Abdullah, dkk (Ed), Dialektika Teks Suci Agama..., hlm. 251-252
} Qur'an..., hlm. 25

16 LPTQ, 25 Tahun Musabaqah Tilawatil
Thaba, inilah awal hubungan antagonistic Islam dan negara (1966-1988). ${ }^{18}$ Hal ini juga terlihat dari kegagalan para tokoh Islam yang ingin menghidupkan kembali Masyumi. Ditambah dengan mencuatnya isu menjadikan Islam sebagai ideologi negara. Semuanya ditolak pemerintah karena beranggapan bahwa yang utama adalah pembangunan ekonomi, sedangkan pembangunan politik hanya bertugas sebagai penunjang dengan menciptakan stabilitas politik yang salah satunya dengan mengurangi peran agama dalam struktur politik.

Menurut Abdul Aziz Thaba, bentuk hubungan yang kedua adalah hubungan yang bersifat resiprokal-kritis yang terjadi antara tahun 1982-1985. ${ }^{19}$ Masa ini ditandai dengan upaya saling mempelajari dan memahami posisi masing-masing. Pemerintah menawarkan konsep asas tunggal bagi orsospol dan ormas di seluruh Indonesia. Gagasan ini juga menimbulkan pro-kontra karena muncul kekhawatiran di kalangan umat Islam dengan menghapus asas ciri Islam, Pancasila akan menjadi "agama baru". ${ }^{20}$

Setelah melewati proses saling memahami, negara menyatakan bahwa umat Islam "lulus ujian". Umat Islam pun semakin memahami kebijakan negara tidak akan menjauhkan mereka dari ajaran Islam (sekularisasi). Menurut Abdul Aziz Thaba, inilah permulaan hubungan yang saling mengakomodasi. Sementara dari sisi lain jika diteliti, sikap pemerintah yang mulai melunak ini dikarenakan berpindahnya arah pandangan Soeharto kepada Soedarmono yang terkesan tidak mengancam kekuasaannya dan Soedarmono yang juga diketahui banyak merekrut tokoh-tokoh partai politik santri dan memberikan tempat lebih besar dari kalangan sipil. Hal ini mengakibatkan melemahnya

18 Abdul Aziz Thaba, Islam dan Negara dalam Politik Orde Baru. (Jakarta: Gema Insani Press, 1996), hlm. 240

${ }^{19}$ Ibid., hlm. 262

${ }^{20}$ Ibid. 
dukungan sebagian perwira tinggi militer terhadap kekuasaan Orde baru. Hal ini memaksa pemerintah untuk meraih dukungan dan legitimasi yang luas dari umat Islam untuk mempertahankan eksistensi kekuasaannya. Dalam konteks inilah banyak "konsesi" diberikan kepada Islam. Kalangan pengamat politik menyebutkan kecenderungan ini sebagai "politik akomodasi" terhadap Islam. ${ }^{21}$

Selanjutnya, bentuk akomodasi pemerintah Orde Baru terhadap Islam ada empat macam, yaitu akomodasi struktural, akomodasi legislatif, akomodasi infrastruktural dan akomodasi kultural. ${ }^{22}$ Yang dimaksud dengan akomodasi structural adalah diakomodasinya atau direkrutnya para tokoh muslim pada lembaga-lembaga eksekutif (birokrasi) dan lembaga-lembaga legislatif negara. Mengenai akomodasi secara struktural ini baru terlihat dengan jelas ketika Presiden Soeharto menyetujui didirikannya ICMI (Ikatan Cendekiawan Muslim Indonesia) pada 1990. Sedangkan akomodasi legislatif berkaitan dengan dikeluarkannya undang-undang atau peraturanperaturan yang berkaitan dengan Islam sebagai aturan yang mandiri dan sah. Di antara kebijakan akomodasi ini adalah pengesahan UU Pendidikan Nasional tahun 1989, pemberlakuan undang-undang peradilan agama, diperbolehkannya pemakaian jilbab pada tahun 1991 serta disahkannya undang-undang yang berkaitan dengan perbankan syariah di Indonesia pada tahun 1992.23

Adapun akomodasi infrastruktural adalah penyediaan infrastruktur yang diperlukan umat Islam untuk melakukan kewajibankewajban agama mereka. Salah satu bentuk dari akomodasi ini adalah kesediaan pemerintah, bukan hanya mengizinkan, tapi juga membantu pendirian Bank Muamalat Indonesia (BMI) pada

21 Hairus Salim, "Sejarah Kebijaksanaan Kerukunan" dalam BASIS, Tahun ke-53 No. 01-02, Januari- Februari 2004, hal. 35

22 Bachtiar Effendy, Islam dan Negara: Transformasi Pemikiran dan Praktek Politik Islam di Indonesia, (Jakarta: Paramadina, 1998), hlm. 40-45.

41

${ }_{23}$ Bachtiar Effendy, Islam dan Negara..., hlm.
1991. Sementara itu akomodasi kultural adalah diperbolehkannya secara luas berbagai ekspresi kebudayaan yang dipahami sebagai Islam. ${ }^{24}$ MTQ bisa dikatakan termasuk kelompok akomodasi yang terakhir ini. Jika ditinjau dari perspektif kepentingan umat Islam, maka kepentingan umat Islam terakomodasi. Dalam perspektif negara, MTQ menguatkan stabilitas nasional dengan menjaga harmonitas antara pemerintah dan umat Islam.

\section{KESIMPULAN}

Dalam sejarah Islam, seni merupakan fenomena yang sedikit banyak memiliki keterkaitan dengan kesadaran religius seseorang yang mengekspresikannya. AlQuran diyakini merupakan sebuah kitab suci yang memiliki bahasa yang indah, yang bahkan tak seorang pun mampu menandinginya. Keindahan bahasa al-Quran ini dalam banyak hal telah mendorong umat Islam untuk mengekspresikan keindahannya dalam berbagai bentuk misalnya melagukan dalam pembacaannya. Upaya mengekspresikan alQuran secara estetik sesungguhnya sudah muncul sejak zaman Nabi Muhammad Saw. Salah satu kisah yang cukup populer adalah tentang kisah keislaman Umar ibn Khattab setelah mendengar pembacaan beberapa ayat Alquran oleh adik perempuannya yang bernama Fatimah bersama suaminya yang bernama Sa'id bin Zayd. Oleh karena itu MTQ merupakan kesempatan untuk mengembangkan seni membaca Alquran, dan ajang untuk menumbuhkan kesadaran untuk membaca dan mempelajari Alquran. 


\section{DAFTAR KEPUSTAKAAN}

Ayoub, Mahmoud. "The Qur'an Recited", dalam http://w3fp.arizona.edu/mesassoc/Buletin/Ayoub

Effendy, Bachtiar. Islam dan Negara: Transformasi Pemikiran dan Praktek Politik Islam di Indonesia, Jakarta: Paramadina, 1998

Irwan Abdullah, dkk (Ed), Dialektika Teks Suci Agama: Strukturisasi Makna Agama dalam Kehidupan Masyarakat, Yogyakarta: Pustaka Pelajar, 2008

LPTQ, 25 Tabun Musabaqah Tilawatil Qur'an dan 17 tabun Lembaga Pengembangan Tilawatil Qur'an, Jakarta: Lembaga Pengembangan Tilawatil Qur'an Tingkat Nasional, 1415H/1994 M

LPTQ Provinsi DKI Jakarta, Dari Jakarta Untuk Indonesia Sejarah LPTQ Provinsi DKI Jakarta, Jakarta: LPTQ Provinsi DKI Jakarta, 2008

Manzur, Ibn. Lisân al-'Arab, Ttp: Dâr Ihya' al-Turast al-'Araby, 630 H

Al-Nawâwî, Abu Zakariya bi Syarf. al-Tibyân fi Ādâb Hamalah Alquran, Beirut: Dâr Ibn Hazm, tth

Nelson, Christina. The Art of Reciting the Qur'an, USA: University of Texas Press, 1985

Pradopo, Rachmat Djoko. "Estetika Resepsi dan Teori Penerapannya", dalam Sulastri Sutrisno (Ed) dkk, Bahasa, Sastra, dan Budaya, Yogyakarta: UGM Press, 1991

Salim, Hairus. "Sejarah Kebijaksanaan Kerukunan” dalam BASIS, Tahun ke-53 No. 01-02, Januari- Februari 2004

Shihab, Quraish. Mu'jizat Alquran, Bandung: Mizan, 1997

Thaba, Abdul Aziz. Islam dan Negara dalam Politik. Orde Baru. Jakarta: Gema Insani Press, 1996 